Article

\title{
Investigation on the Mechanical Properties and Post-Cracking Behavior of Polyolefin Fiber Reinforced Concrete
}

\author{
Suman Kumar Adhikary* $*$, Zymantas Rudzionis $₫$, Arvind Balakrishnan and \\ Vignesh Jayakumar \\ Faculty of Civil Engineering and Architecture, Kaunas University of Technology, LT-44249 Kaunas, Lithuania; \\ zymantas.rudzionis@ktu.lt (Z.R.); arvind.balakrishnan@ktu.edu (A.B.); Avicky5593.1@gmail.com (V.J.) \\ * Correspondence: sumankradk9s@gmail.com; Tel.: +91-820-724-6551
}

Received: 29 November 2018; Accepted: 18 January 2019; Published: 20 January 2019

check for updates

\begin{abstract}
This paper deals with the behavior of concrete's self-compatibility in a fresh state and its compressive and flexural strength in a hardened state with the addition of polyolefin macro fibers. Four different amounts $\left(3 \mathrm{~kg} / \mathrm{m}^{3}, 4.5 \mathrm{~kg} / \mathrm{m}^{3}, 6 \mathrm{~kg} / \mathrm{m}^{3}\right.$, and $\left.9 \mathrm{~kg} / \mathrm{m}^{3}\right)$ of polyolefin macro fibers were mixed into the concrete mixture to observe the differences in workability and strength properties between the concrete specimens. As a partial replacement of cement, class $C$ type of fly ash was added to make up $25 \%$ of the total cement mass. The water-binder ratio (W/B) of the concrete mix was 0.36 . Superplasticizer was added to the concrete mixture to achieve self-compacting properties. The slump test was carried out in the fresh state for determining the flowability. On the 7th and 28th days of the curing process, compression strength tests were performed, and on the 28th day, flexural strength tests and crack mouth opening displacement (CMOD) analyses were carried out to determine the strength properties and post-cracking behavior of the concrete samples. Bending strength and post-cracking behavior of the samples were improved by the addition of fibers. The fiber concentration in the concrete mixture greatly influenced the slump flow and self-compaction properties.
\end{abstract}

Keywords: polyolefin fiber; CMOD test; post cracking behavior; bending strength; fly ash concrete

\section{Introduction}

In the construction industry, self-compacting concrete is widely used because of its various beneficial properties. In 1988, the concept of self-compacting concrete was developed to obtain more strength and durable properties [1]. Self-compacting concrete is a special type of concrete which provides high flowability without any segregation [2]. This type of concrete is very useful for difficult casting conditions and reduces the overall construction cost. To obtain higher flowability and workability in self-compacting concrete, superplasticizers or chemical admixtures are necessary; superplasticizers can change the concrete viscosity. To increase concrete viscosity, different types of fillers such as fly ash, silica fume, quartzite filler, and stone powder, etc., are used [3]. Partial amounts of fly ash can be used as a replacement of cement. Fly ash has various benefits such as increasing the workability, decreasing the permeability, and increasing the cohesiveness of concrete [4]. It has been found that a $20 \%$ replacement of fly ash by cement mass in concrete gives higher compressive strength [5]. In the past few years, use of fibers in concrete mixture has been gaining considerable attention. Due to environmental exposure, poor construction and presence of chloride ions in concrete leads to corrosion, micro cracks, degradation, and steel corrosion. Fibers are becoming a very useful material to overcome these types of problems because of its various benefits. Normal conventional standard concrete and self-compacted concrete both have good compressive strength with low tensile 
strength. The addition of a small quantity of fibers can decrease shrinkage cracking [6] and also increase toughness and tensile strength [7]. Nowadays in the market, different types of fibers are available in different geometrical shapes. Fibers can be manufactured using various kinds of materials like steel, carbon, palm, polypropylene, glass, synthetic, and natural materials $[8,9]$. Steel fibers are the most widely used fibers because of its high modules of elasticity and tensile strength. Steel fibers are used to decrease the thickness, obtaining higher strength properties, and it is applied in road construction, pre-cast concrete, tunnels, airports, and the building industry. Over recent years, extensive studies have been done on steel fiber reinforced concrete to increase mechanical properties and durability [10-15]. Steel fibers have various benefits, but it leads to steel corrosion and cracks in certain environmental conditions. Various studies were carried out and studies are still being carried out to reduce the problem of steel corrosion [16-20]. Polyolefin fibers are widely used nowadays because of significant benefits such as increasing concrete strength and decreasing the unit weight of concrete [21]. Polyolefin fibers have a greater influence in terms of strength, ductility, and flexibility compared to steel fibers [22,23]. Polyolefin fibers are lighter in weight than steel fibers and they have no reactions with water. Polyolefin fiber reinforced concrete show better results in terms of steel corrosion and cracks [24]. Polyolefin fibers have better boding properties with concrete because of its shape and rough design. Polyolefin fiber reinforced concrete also gives higher bending strength. From the past few years, researchers have been conducting experimental studies on the beneficial aspects of polyolefin fibers in normal conventional concrete, lightweight concrete, foamed concrete, and high-performance concrete [25-27].

\section{Used Materials}

In this study, $2 \mathrm{~mm}$ and $4 \mathrm{~mm}$ sizes of local sand (fine aggregate), local coarse aggregate, and ordinary Portland cement satisfying EN 197-1:2011 [28] of grade CM I 42.5 (Rocket cement M-600, AB Cementa, Stockholm, Sweden) were used. The class C type of fly ash was used in the concrete mixture. Masterglenium SKY 8700 [29] superplasticizer was added to the concrete mix to achieve the self-compatibility properties. Four different amounts of rough-surface-designed polyolefin macro fibers were used in the concrete mixture. The properties of the polyolefin macro fiber is shown in Figure 1.
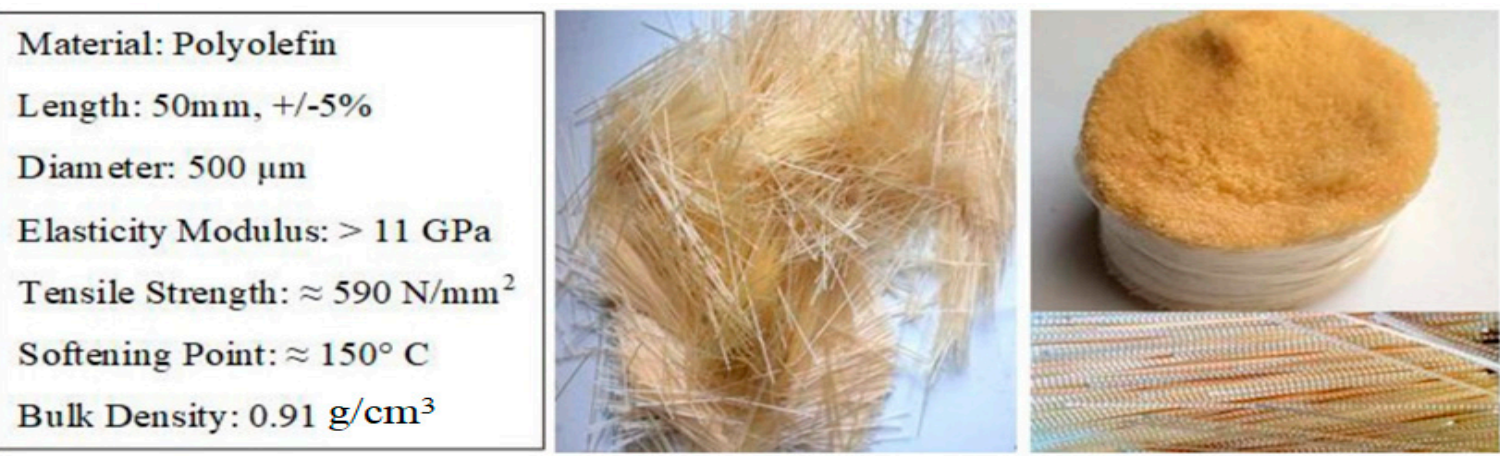

Figure 1. Properties of polyolefin macro fibers.

Four types of concrete were prepared with various amounts of fiber content. The samples were named S-1, S-2, S-3, and S-4, which contains $3 \mathrm{~kg} / \mathrm{m}^{3}, 4.5 \mathrm{~kg} / \mathrm{m}^{3}, 6 \mathrm{~kg} / \mathrm{m}^{3}$, and $9 \mathrm{~kg} / \mathrm{m}^{3}$ of macro polyolefin fibers in concrete matrix, respectively. Class $C$ type of fly ash was added by $25 \%$ of total cement mass in the concrete as a partial replacement of cement. A 0.36 water-binder (cement + fly ash) ratio was maintained for each of the concrete samples. In every type of concrete sample, the quantity aggregates, cement, fly ash, water-binder ratio, and quantity of superplasticizer was the same, and only the quantity of fibers were changed to observe the behavior of the concrete with varying levels of fiber concentration. The mixing proportions of all concrete samples are given in Table 1. After mixing the concrete sample, the slump test was performed for each type of concrete sample, and thereafter, all 
samples were molded. Cubes of $10 \mathrm{~cm} \times 10 \mathrm{~cm} \times 10 \mathrm{~cm}$ in size were prepared for the compressive strength test while $40 \mathrm{~cm} \times 10 \mathrm{~cm} \times 10 \mathrm{~cm}$ sized prisms were prepared for the crack mouth opening displacement (CMOD) analysis. After the molding process, all types of samples were kept at room temperature for $24 \mathrm{~h}$ for the hardening process. After the process, all samples were demolded and kept immersed in water in a climatic chamber until the day of the concrete destructive tests.

Table 1. Mixing proportions of concrete.

\begin{tabular}{ccc}
\hline Materials Used for Concrete Mixture Preparation & Quantity of the Materials for $\mathbf{1} \mathbf{~ m}^{\mathbf{3}}$ Concrete \\
\hline Fine aggregate & $2 \mathrm{~mm}$ & $160.5 \mathrm{~kg}$ \\
& $4 \mathrm{~mm}$ & $696.8 \mathrm{~kg}$ \\
\hline Coarse aggregate & \multicolumn{2}{c}{$827.9 \mathrm{~kg}$} \\
Cement & $400 \mathrm{~kg}$ \\
Water & $181.6 \mathrm{~kg}(\mathrm{~W} / \mathrm{B}$ ratio 0.36$)$ \\
Fly ash & $100 \mathrm{~kg}(25 \%$ of cement mass $)$ \\
Super plasticizer & $7.5 \mathrm{~kg}(1.5 \%$ of cement mass $)$ \\
\hline Polyolefin fibers & $\mathrm{S}-1$ & $3 \mathrm{~kg}$ \\
& $\mathrm{~S}-2$ & $4.5 \mathrm{~kg}$ \\
& $\mathrm{~S}-3$ & $6 \mathrm{~kg}$ \\
& $\mathrm{~S}-4$ & $9 \mathrm{~kg}$ \\
\hline
\end{tabular}

\section{Mechanical Properties Evolution}

For the first step, the concrete was mixed carefully according to the designed proportions. After the mixing procedure, the slump flow test was performed according to the EN 12,350-2:2009 [30] standard. For each type of sample, the slump flow test was performed three times and the mean value was taken as the final result. The slump flow value of the concrete specimens decreased with increasing amounts of polyolefin fibers in the concrete mixture. Segregation and bleeding were not observed for any type of sample. Sample S-4 showed a very low slump value and lost its self-compacting properties. Figure 2 shows the variations of slump flow values according to the sample types.

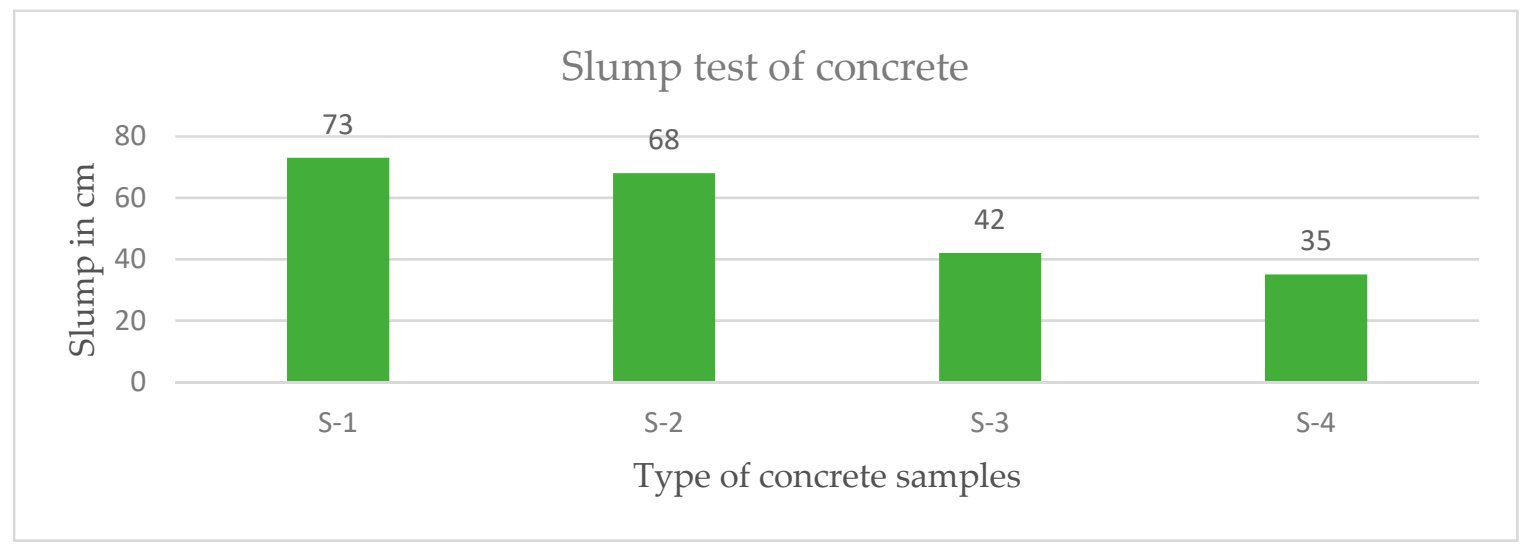

Figure 2. Slump value of concrete specimens.

Concrete compressive tests was performed on the 7th and 28th days of the curing process, satisfying the EN 196-1:2016 [31] standard. For each type of concrete sample, three tests were conducted for compressive strength and flexural test, and the mean value was taken as the final result. The peak force on CMOD analysis was considered to be the flexural strength of the concrete samples. The compressive strength of concrete samples on the 7th day increased with increasing amounts of fiber content in the concrete mixture, and then it decreased. The same phenomenon was observed on the 
28th day for the compressive strength test. Sample S-3 achieved higher compressive strength on the 7th day while sample S-2 achieved higher compressive strength on the 28th day. This phenomenon could be due to the addition of fly ash in the concrete. Previously, researchers showed that the presence of fly ash in concrete delays the hydration process and the concrete has low strength in the early stages, and the concrete improves in strength at a later stage (after 60 days) [32,33]. The variations in compressive strength are shown in Figure 3.

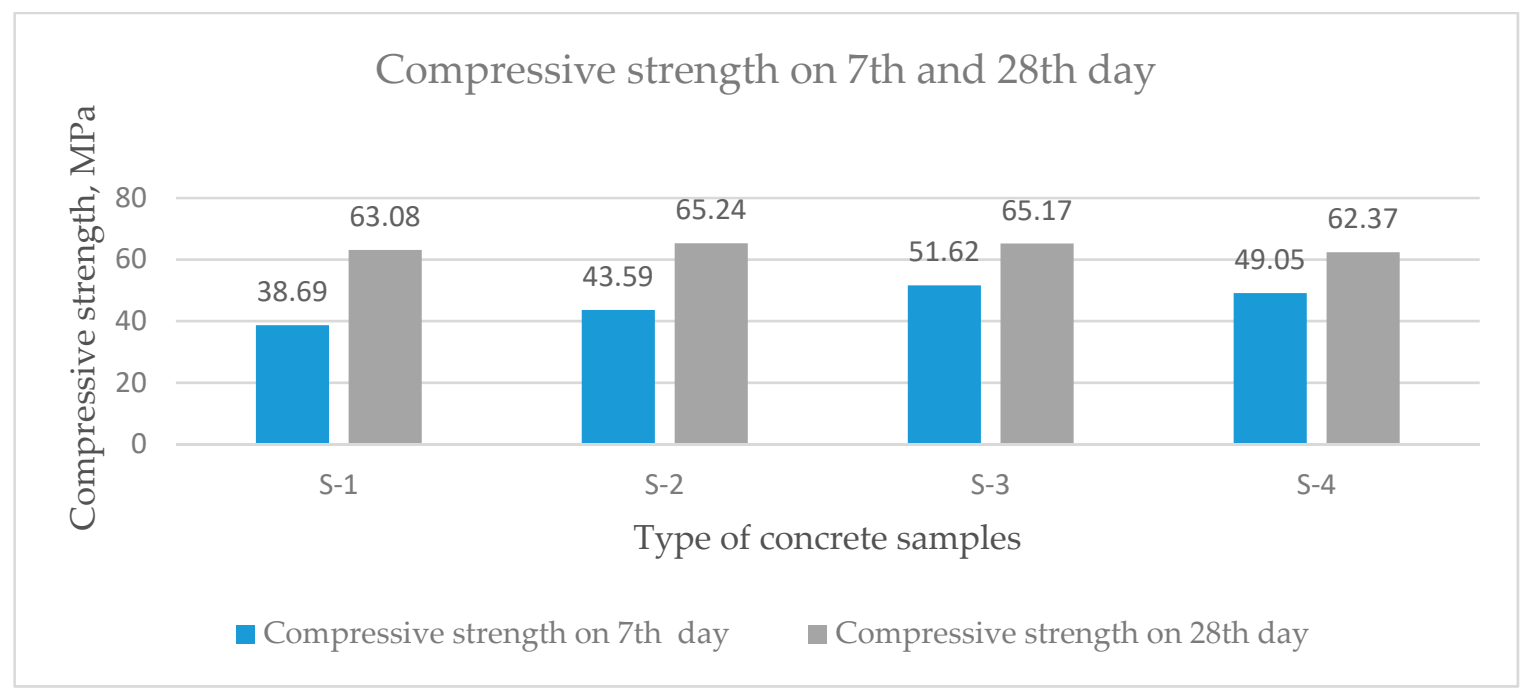

Figure 3. Compressive strength of concrete samples on the 7th and 28th days.

Through the three-point bending test method, CMOD analysis was performed on the 28th day of the curing process, satisfying the EN $14651+$ A1:2007 [34] standard. All the samples were tested until the concrete broke and large cracks were formed, although the concrete was not separated into two parts. The concrete broke and cracks were formed, but the fibers were holding the concrete and resisted the separation. Polyolefin fibers have good bonding properties, and its rough design helps to hold the concrete together after cracks have formed. Figure 4 shows the concrete cracks after the test. The peak force was taken as an indication of flexural strength. Sample S-4 has higher bending strength which increased with the addition of fibers in the concrete mixture. In a previous experimental study, it has been found that bending strength increases with the addition of polyolefin macro fibers till a certain proportion in the concrete mixture, and then the strength started decreasing [35]. Figure 5 shows the variations of flexural strength of concrete samples on the 28th day.
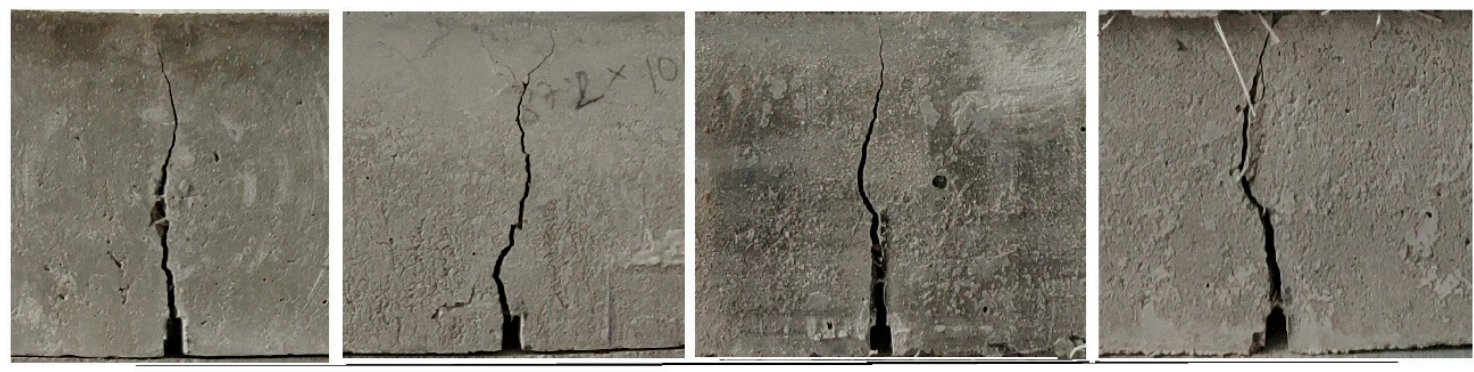

Figure 4. Concrete cracks after the test. 


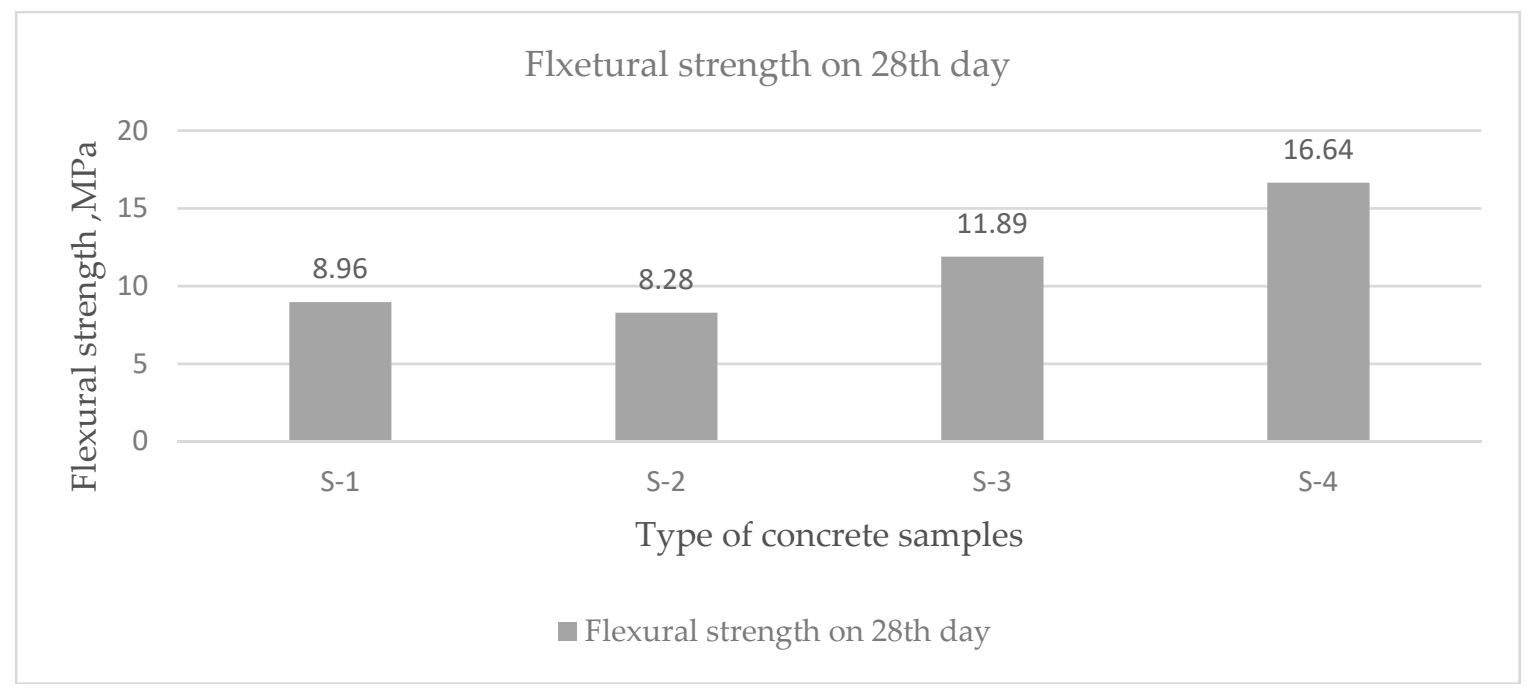

Figure 5. Flexural strength of concrete samples on the 28th day.

\section{Post-Cracking Behavior Analysis}

Before the CMOD analysis, all water-immersed prisms were taken from the climatic chamber and dried for a few hours. After the drying process, all the prisms were given a cut $1 \mathrm{~cm}$ deep (down the height of the prism) at the midpoint of their lengths. An extensometer apparatus was fixed to the concrete surface by using a suitable glue. CMOD analysis was performed until the concrete breaks reached a $4.5 \mathrm{~mm}$ displacement. The loading speed of the CMOD analysis was $0.6 \mathrm{~mm} / \mathrm{min}$. After the $4.5 \mathrm{~mm}$ displacement, each sample remained in a single piece because of the higher fiber concentration; the fibers held the concrete and resisted the separation of the concrete into two pieces. Figure 6 shows the prism setup for the CMOD analysis. According to the EN 14651 + A1:2007 [34] standard, concrete should have a higher strength than $1.5 \mathrm{MPa}$ and $1 \mathrm{MPa}$ at 0.5 and $3.5 \mathrm{~mm}$ displacement, respectively. Figures 7 and 8 shows that sample S- 1 had about $4 \mathrm{MPa}$ of strength at $0.5 \mathrm{~mm}$ displacement, and at $3.5 \mathrm{~mm}$ displacement, it had 4.3 MPa of strength. It had the highest strength of $8.96 \mathrm{MPa}$. Sample S-3 and S-4 showed better cracking behavior than S-1 and S-2. Previously, researchers found that a higher volume of fibers in the concrete mix significantly improves the post-cracking behavior [36,37]. Sample S-3 and S-4 showed higher strength at $3.5 \mathrm{~mm}$ displacement than at $0.5 \mathrm{~mm}$ displacement. Sample S-3 had the highest strength at $0.25 \mathrm{~mm}$ displacement, and S-4 showed the highest strength performance at $2.30 \mathrm{~mm}$ displacement.

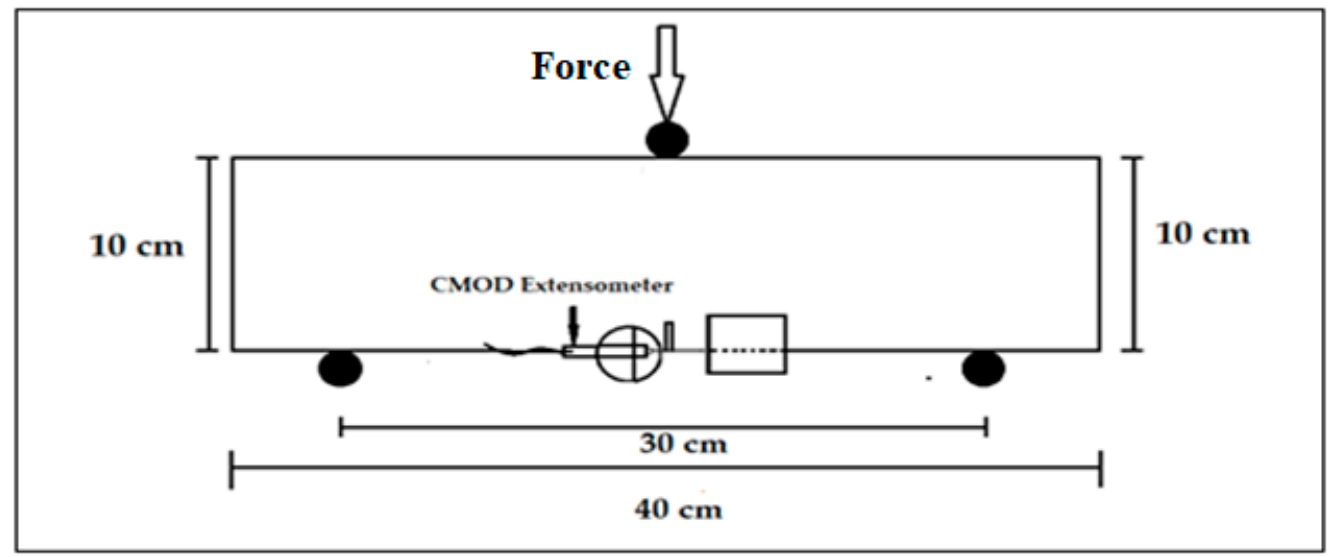

Figure 6. Setup for the crack mouth opening displacement (CMOD) test. 

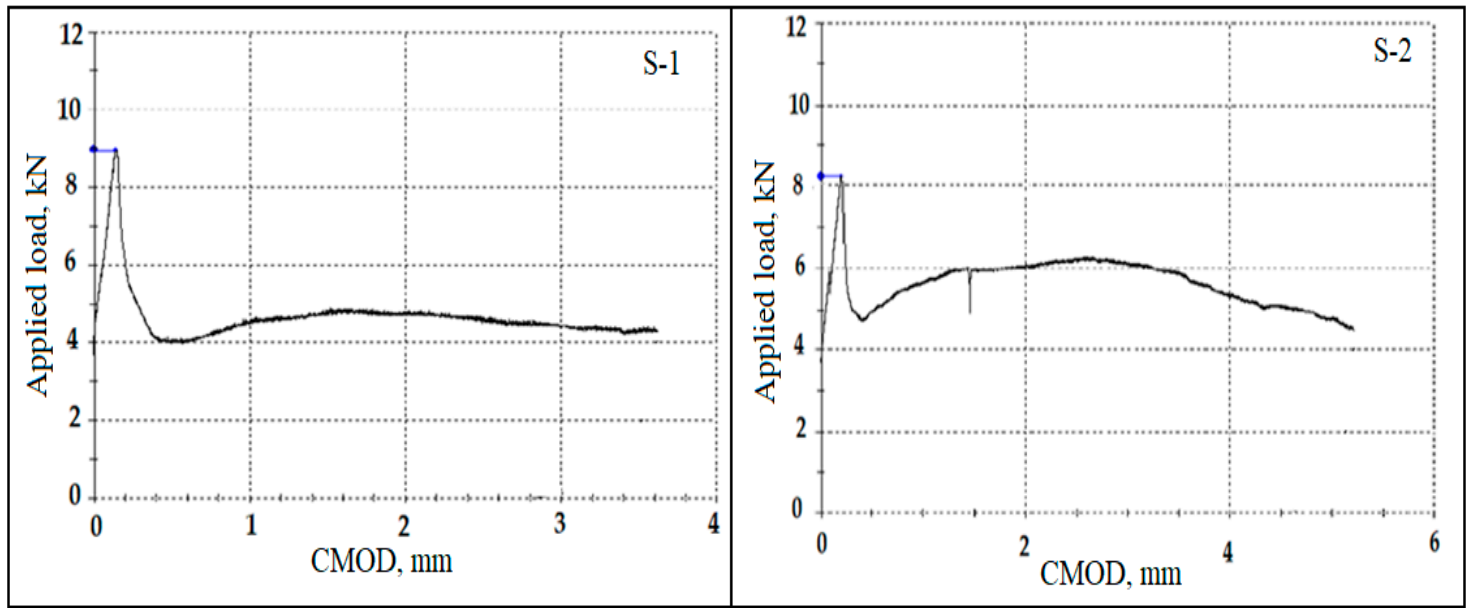

Figure 7. Load-CMOD curves of S-1 and S-2.

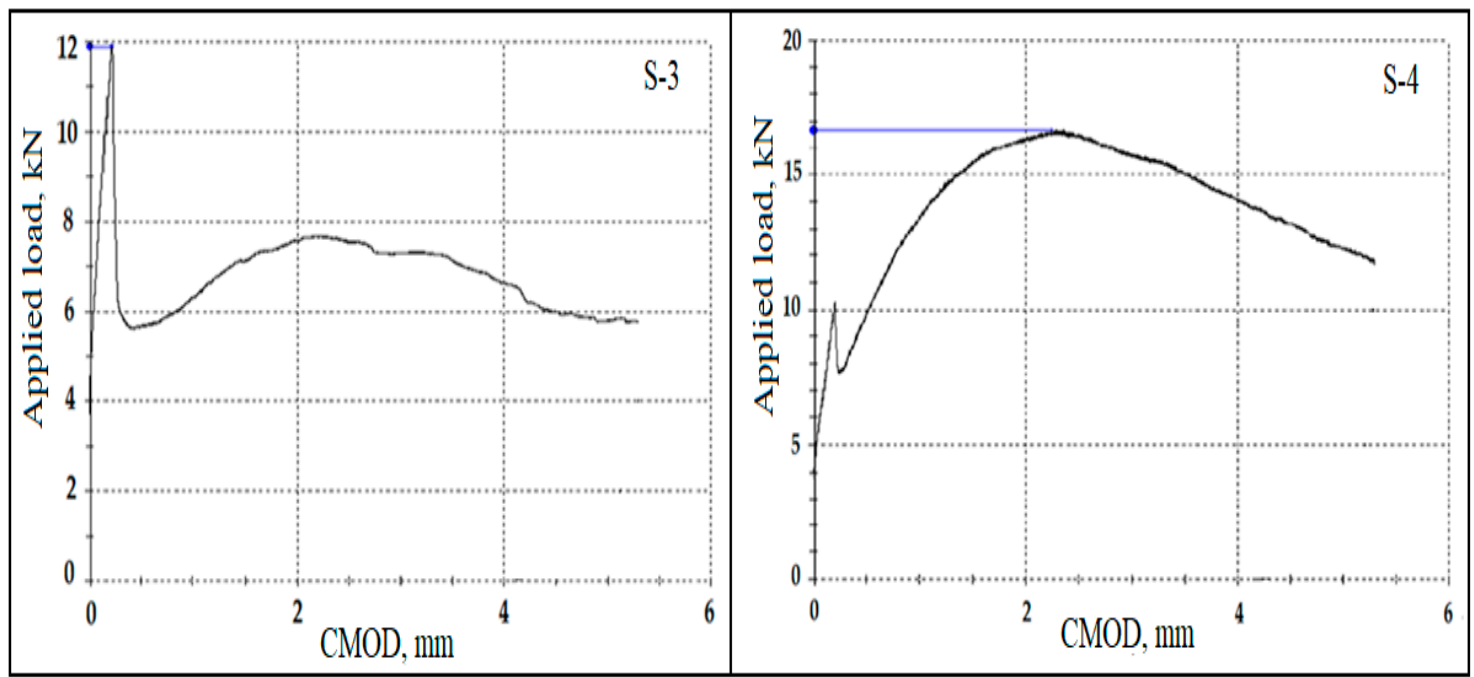

Figure 8. Load-CMOD curves of S-3 and S-4.

\section{Conclusions}

The study showed that samples S-1, S-2, and S-3 achieved better flowability than S-4 with no segregation and bleeding. Meanwhile, for sample S-4, segregation and bleeding was not observed but the slump value was much lower because of the higher fiber concentration. Sample S-4 also lost the self-compaction properties. In terms of strength properties, sample S-2 achieved higher compressive strength on the 28th day of the test, and thereafter strength started decreasing for S-3 and S-4. Flexural strength of the concrete samples increased with increasing fiber quantity in the concrete mixture. Sample S-4 achieved higher bending strength among all the samples. The post-cracking behavior of the concrete samples were improved by the addition of fiber. Samples S-3 and S-4 had better results than S-1 and S-2 because of higher number of fibers in their cross-sections. The rough surface design of polyolefin fibers helps to increase the bending strength and post-cracking behavior of concrete. Samples S-3 and S-4 had higher fiber quantity than samples S-1 and S-2, and as a result, they showed better post-cracking behavior.

In conclusion, polyolefin fibers have great influence on concrete strength and self-compaction properties. Higher doses of polyolefin fibers provide better flexural strength, and post-cracking behavior was also improved by the addition of fibers. The compressive strength of concrete also decreases with the addition of fibers. On the other hand, the slump flow and self-compaction factor of concrete decreases with the addition of fibers. Concrete can also completely lose the self-compaction properties. 
In this study, sample S-3 can be used in the construction sector where self-compacting properties, higher bending, and compressing strength is needed. This sample showed the best results in terms of higher bending strength and post-cracking behavior without compromising self-compaction properties.

In a previous experimental study, it was found that a $10 \mathrm{~kg} / \mathrm{m}^{3}$ density of polyolefin fiber achieves higher bending strength [35], and in this study, sample S-4, with the fiber density of $9 \mathrm{~kg} / \mathrm{m}^{3}$, achieved higher bending strength while compromising self-compaction properties and a small amount of compressive strength.

Author Contributions: This paper consists of a combination of efforts from four authors: S.K.A., Z.R., A.B., and V.J. Preparation of samples, experimental work, analysis of data, and drafting of the manuscript were done jointly.

Funding: This research and the APC was funded by Kaunas University of technology.

Acknowledgments: All the materials and support for tests were received from the Faculty of Civil Engineering and Architecture, Kaunas University of Technology, Kaunas LT-44249, Lithuania. We are grateful to acknowledge their support for their contribution and help.

Conflicts of Interest: The authors declare no conflicts of interest.

\section{References}

1. Okamura, H.; Ouchi, M. Self-compacting concrete. J. Adv. Concr. Technol. 2003, 1, 5-15. [CrossRef]

2. D'aloia, L.; Schwartzentruber, R.; Roy, L.; Cordin, J. Rheological behaviour of fresh cement pastes formulated from a self-compacting concrete (SCC). Cem. Concr. Res. 2006, 36, 1203-1213.

3. Nagamoto, N.; Ozawa, K. Mixture properties of self-compacting, high-performance Concrete. In Proceedings of the Third CANMET/ACI International Conferences on Design and MATERIALS and Recent Advances in Concrete Technology, Kuala Lumpur, Malaysia, 2-5 December 1997; pp. 623-637.

4. Davis, R.E. Pozzolanic Materials with Special Reference to Their Use in Concrete Pipe; Technical Memorandum; American Concrete Pipe Association: Irving, TX, USA, 1954; pp. 14-15.

5. Goud, V.; Soni, N.; Varma, G.; Kushwah, K.; Chaurasia, S.; Sharma, V. Partial replacement of cement with fly ash in concrete and its effect. IOSR J. Eng. 2016, 6, 69-75.

6. Banthia, N.; Gupta, R. Influence of polypropylene fiber geometry on plastic shrinkage cracking in concrete. Cem. Concr. Res. 2006, 36, 1263-1267. [CrossRef]

7. Shah, S.; Rangan, B. Fiber reinforced concrete properties. J. Am. Concr. Inst. 1971, 68, 126-135.

8. Brandt, A.M. Fibre reinforced cement-based (FRC) composites after over 40 years of development in building and civil engineering. Compos. Struct. 2008, 86, 3-9. [CrossRef]

9. Ivorra, S.; Garcés, P.; Catalá, G.; Andión, L.G.; Zornoza, E. Effect of silica fume particle size on mechanical properties of short carbon fiber reinforced concrete. Mater. Des. 2010, 31, 1553-1558. [CrossRef]

10. Błaszczyński, T.; Przybylska-Fałek, M. Steel fibre reinforced concrete as a structural material. Procedia Eng. 2015, 122, 282-289. [CrossRef]

11. Nehme, S.G.; László, R.; El Mir, A. Mechanical performance of steel fiber reinforced self-compacting concrete in panels. Procedia Eng. 2017, 196, 90-96. [CrossRef]

12. Nilforoush, R.; Nilsson, M.; Elfgren, L. Experimental evaluation of tensile behaviour of single cast-in-place anchor bolts in plain and steel fibre-reinforced normal- and high-strength concrete. Eng. Struct. 2017, 147, 195-206. [CrossRef]

13. Pajaka, M.; Ponikiewski, T. Investigation on concrete reinforced with two types of hooked fibers under flexure. Procedia Eng. 2017, 193, 128-135. [CrossRef]

14. Raczkiewicz, W. The effect of micro-reinforcement steel fibers addition on the size of the shrinkage of concrete and corrosion process of the main reinforcement bars. Procedia Eng. 2017, 195, 155-162. [CrossRef]

15. Aylie, H.; Okiyarta, A.W. Experimental study of steel-fiber reinforced concrete beams with confinement. Procedia Eng. 2015, 125, 1030-1035. [CrossRef]

16. Alizade, E.; Jandaghi, A.F.; Zabihi, S. Effect of steel fiber corrosion on mechanical properties of steel fiber reinforced concrete. Asian J. Civ. Eng. 2016, 17, 147-158.

17. Berrocal, C.G.; Lundgren, K.; Löfgren, I. Influence of steel fibers on corrosion of reinforcement in concrete in chloride environments: A review. In Proceedings of the 7th International Conference Fibre Concrete 2013, Prague, Czech Republic, 12-13 September 2013. 
18. Anandan, S.; Manoharan, S.V.; Sengottian, T. Corrosion effects on the strength properties of steel fibre reinforced concrete containing slag and corrosion inhibitor. Int. J. Corros. 2014, 2014, 595040. [CrossRef]

19. Granju, J.L.; Balouch, S.U. Corrosion of steel fiber reinforced concrete from the cracks. Cem. Concr. Res. 2005, 35, 572-577. [CrossRef]

20. Mihashi, H.; Ahmed, S.F.U.; Kobayakawa, A. Corrosion of reinforcement steel in steel fiber reinforced concrete structures. J. Adv. Concr. Tech. 2011, 9, 159-167. [CrossRef]

21. Bagherzadeh, R.; Pakravan, H.R.; Sadeghi, A.; Latifi, M.; Merati, A.A. An investigation on adding polypropylene fibers to reinforce lightweight cement composites. J. Eng. Fibers Fabr. 2012, 7, 13-19. [CrossRef]

22. Tagnit, A.; Vanhove, Y.; Petrov, N. Microstructural analysis of the bond mechanism between polyolefin fibers and cement pastes. Cem. Concr. Res. 2005, 35, 364370.

23. Neeley, B.D.; O'Neil, E.F. Polyolefin fiber reinforced concrete. In Proceedings of the Materials Engineering Conference: Materials for the New Millennium, Washington, DC, USA, 10-14 November 1996; Volume 1, pp. 113-122.

24. Lin, W.; Cheng, A. Effect of polyolefin fibers and supplementary cementitious materials on corrosion behavior of cement-based composites. J. Inorg. Organomet. Polym. 2013, 23, 888-896. [CrossRef]

25. Mindess, S.; Wang, N.; Rich, L.D.; Morgan, D.R. Impact resistance of polyolefin fiber reinforced precast units. Cem. Concr. Compos. 1998, 20, 387-392. [CrossRef]

26. Wan Ibrahim, M.H.; Jamaludin, N.; Irwan, J.M.; Ramadhansyah, P.J.; Suraya Hani, A. Compressive and flexural strength of foamed concrete containing polyolefin fibers. Adv. Mater. Res. 2014, 91, 489-493. [CrossRef]

27. Maruthachalam, D.; Padmanaban, I.; Vishnuram, B.G. Influence of polyolefin macro-monofilament fibre on mechanical properties of high-performance concrete. Ksce J. Civ. Eng. 2013, 17, 1682-1689. [CrossRef]

28. Cement. Composition, Specifications and Conformity Criteria for Common Cements; BS EN 197-1:2011; BSI: London, UK, 2011.

29. MasterGlenium ${ }^{\circledR S K Y}$ 8700, BASF New generation superplasticising admixture for extended slump retention. Technical data sheet. Available online: https: / assets.master-builders-solutions.basf.com/shared\%20documents / pdf/english\%20(australia)/basf-masterglenium-sky-8700-tds.pdf (accessed on 20 November 2018).

30. Testing Fresh Concrete, Part 2: Slump-Test; BS EN 12350-2; BSI: London, UK, 2009.

31. Methods of Testing Cement. Part 1: Determination of Strength; BS EN 196-1:2016; BSI: London, UK, 2016; ISBN 9780580845802.

32. Feng, J.; Sun, J.; Yan, P. The influence of ground fly ash on cement hydration and mechanical property of mortar. Adv. Civ. Eng. 2018, 2018, 4023178. [CrossRef]

33. Saha, A.K. Effect of class F fly ash on the durability properties of concrete. Sustain. Environ. Res. 2018, 28, 25-31. [CrossRef]

34. Test Method for Metallic Fibre Concrete Measuring the Flexural Tensile Strength (Limit of Proportionality (LOP), Residual); BS EN 14651:2005+A1:2007; BSI: London, UK, 2005.

35. Adhikary, S.K.; Rudzionis, Z. Behavior of concrete under the addition of high volume of polyolefin macro fiber and fly ash. Fibers 2018, 6, 38. [CrossRef]

36. Rizzuti, L.; Bencardino, F. Effects of Fibre Volume Fraction on the Compressive and Flexural Experimental Behaviour of SFRC. Contemp. Eng. Sci. 2014, 7, 379-390. [CrossRef]

37. Bencardino, F.; Rizzuti, L.; Spadea, G.; Swamy, R.N. Implications of test methodology on postcracking and fracture behavior of Steel Fibre Reinforced Concrete. Composites Part B 2013, 46, 31-38. [CrossRef]

(c) 2019 by the authors. Licensee MDPI, Basel, Switzerland. This article is an open access article distributed under the terms and conditions of the Creative Commons Attribution (CC BY) license (http://creativecommons.org/licenses/by/4.0/). 